\title{
The Evolution of Education in Nigeria: How has it Impacted Ordinary Nigerians from Pre-Independence till Present?
}

\author{
Abayomi Alase \\ School of Education, Northeastern University, Boston, Massachusetts, USA \\ E-mail: samuel-alase.a@husky.neu.edu; aalase@yahoo.com
}

Received: 06-01-2017

doi:10.7575/aiac.ijels.v.5n.1p.69
Accepted: 17-01-2017

URL: http://dx.doi.org/10.7575/aiac.ijels.v.5n.1p.69

Published: 31-01-2017

\begin{abstract}
This article looked at the maturity of the Nigerian educational system from independence until now. As a comprehensive and historical review of the educational system/standard in Nigeria, this article examine some of the educational issues/shortcomings confronting the Nigerian people, and their inability to anticipate and strategically plan a course of action to handle the stressors. Additionally, this article also discussed the effects of globalization and how it has transformed/reshaped the fundamentalism of educational practices in Africa. As such, the problem with the Nigerian educational system is that it is lacking in many educational areas. It is recommended that the Nigerian government facilitate the development/construction of new infrastructures. For any society to grow/function properly, economically, developmentally, and/or fundamentally it needs certain infrastructures in place, i.e., standardized and structurally sound school buildings.
\end{abstract}

Keywords: Nigerian educational system, UPE in Nigeria, UBE in Nigeria, Public and private universities in Nigeria

\section{Introduction}

On October $1^{\text {st }}$ of 2016, Nigeria turned 56 years old. The country gained her independence on October $1^{\text {st }} 1960$ from the British Government, and ever since she has been chartering and negotiating her destiny. The country started with a population of roughly 43 million in 1960, but now, the country's population has grown to about 170 million according to the 2010 population census. That, however, is where the majority of the country's massive problems originated from, plus the fact that many of the leadership in the country, both the military and civilian governments, were enormously corrupt (Aluko, 2002; Dike, 2005; Ogbeidi, 2012; Ogundiya, 2009). The level of corruption in the country is legendary and the process has hindered and prevented developmental growth in the country. As aforementioned, most of the issues facing Nigeria stemmed from the huge population in the country. The fact of the matter is that no country with the level of political and economic unstableness that existed in Nigeria can sustain such a huge economic burden. Politically, Nigeria has never had a stable democratically elected government without the interruptions (coup d'etats) by the military juntas. Until recently (actually, since the beginning of this new republic that started in 1999), Nigeria's democracy has never seen the light of day without the military juntas interrupting the democratically elected civilian governments. As a matter of fact, military interruptions and coup d'etats have become something of an entrenched history of Nigeria. Since the country gained her independence from Great Britain in 1960, Nigeria has had approximately nine coup d'états; both failed and successful ones. For example the first military coup d'etat in Nigeria was in January of 1966, approximately six years after the nation gained her independence. This coup was led by Major Kaduna Nzeogwu and his cohort. In the same year, 1966, Major General Yakubu Gowon led what was called a counter-coup to overthrow the earlier coup plotters. However, in 1975, General Gowon, himself, was overthrown by another military juntas led by Brigadier Murtala Muhammed. A year later, in 1976, General Muhammed was killed in an unsuccessful coup d'etat led by Lieutenant Colonel Buka Suka Dimka. The history of Nigerian military personnel periodical staging coup d'etats to overthrow either a military government or a democratically elected civilian government is truly legendary. As a consequence, the political and economic stability of the country has been compromised and corrupted; it is going to be almost impossible for any sector in the country's economy, both public and private, to function properly without the country doing a true soul-searching within herself (Aluko, 2002; Augustine \& Uagbale-Ekatah, 2014; Ogbeidi, 2012; Ogundiya, 2009; Okoye, 2016).

As to education in Nigeria, the country's educational system has gone through quite a lot of transformations and reformations that were supposed to change and improve the state of education in the country. However, with the enormous population of school age students numbering in the millions (Asodike \& Ikpitibo, 2014), it is almost impossible for any developing nation to sufficiently finance and manage such a huge enterprise (free education) without major hiccups. Equally important to understand is the fact that dysfunctionality of education in Nigeria stemmed from the ill-planned educational reformations schemes (Universal Primary Education-UPE) of the first republic thru the 1970s military governments, and the subsequence reformations that came after. The problems that education in Nigeria 
faces are the lack of experience needed in formulating a strategically planned and implemented educational reform that are well-conceived. Finally, in addition to the above articulated problems, another problem that education in Nigeria faces is the state of mismanagement in almost every area of the system. For any nation to be prosperous in this globalized marketplace, it is important for that country's educational system to function properly, because only by having a strong educational system can everything else, including technology and economic growth and development, strive and flourish. In other words, globalization depends and work hand-in-hand with strong educational system.

With all that said, it is important that issues in the educational system in Nigeria be investigated (issues as complex and diverse as the educational standards, reformations, functionalities, adult and community educations, gender and special needs educational equalities, etc, must be looked into diligently). This paper will attempt to examine several elements within the educational system for the purpose of understanding and identifying the problems facing the country's educational system. Moreover, this paper's examination will also trace the history of educational reforms in Nigeria as far back as the first republic down to the present day to see if there were any issues that need to be raised and discussed. However, in the end, in the conclusion section, advice will be offered as a contribution to the development and transformation of education in Nigeria.

\title{
2. Globalization of Education in Africa: Nigeria in particular
}

Globalization has transformed the way people interact with each other; it has revolutionalized the movement of resources; capital and labor to places around the world that needed it the most. This phenomenon has made it a little easier for African countries to re-evaluate their educational and economic interests and agendas. It has also created a global village where people of different background can embrace and engage one another in commerce, culture and scholarship. Conceptually, globalization has open up doors of participation in the global resources, i.e., education, economics, politics, Art, and culture. More importantly, the ease of interconnectivity and the openness of new marketplaces and scholarships have made globalization a viable alternative for many remote places around the world. According to Akani (2013), he noted that " The increasing global connectivity and interdependency have ultimately led to fast movement of goods, services, personnel, free flow of foreign direct investment, elimination of statutory and cultural barriers that hinder trade, development of global trade and business ethics" (p. 21). He went on to also note that "The challenge before Africa is daunting. The continent does not have the global instruments to strongly resist the violation of the rights of its people. The result is that human rights in Africa exist at the behest of apostles of globalization" (p. 24). However, in the battle for markets and world domination by the powerful nations on earth, Africa has been marginalized. As a developing continent, African marginalization started after the collapsed of the Soviet Union, Mazrui (1999) argued that

\begin{abstract}
Africa's involvement in the Cold War was another globalizing experience, but in this case marginalization was temporarily suspended. The rivalries between the two super powers temporarily increased Africa's global strategic value and enhanced Africa's influence in the United Nations, UNESCO, the Commonwealth, and a number of other international forums. It was the end of Cold War which reactivated Africa's marginalization. The end of the Cold War was a kind of "disglobalizing” experience. (p. 7)
\end{abstract}

In many instances, globalization has been looked at from the point of view of economic growths and industrialization developments. However, for the purpose of this paper, globalization is going to be looked at from the point of view of educational vitality in Africa. Geo-Jaja (2005) in his argument to illustrates the benefits (or the lack thereof) of globalization in educational reforms and policies in Africa, particularly in Nigeria, stated that the Nigerian educational system cannot be compared with the Western educational systems. He argued that "In this fundamental respect, therefore, the Nigerian education system and its basic orientation seem grossly mismatched with the future needs of their students and with the development needs of the society" (p. 526). Therefore, he asserted that "Evidence has indeed been accumulating to demonstrate that education priorities did, in fact, shift since the imposing of adjustment in the 1980s, with many countries putting new emphasis on staying current on debt service" (p. 522). Additionally, in support of his assertion, UNESCO's, World Education Report, on the educational expenditure by central governments of twenty-six African countries on per pupil in those countries, shows a decline of about 33 percent from 1980 through 1988 (UNESCO, 1998).

Furthermore, according to the World Bank report (1996, p. 18), the report indicated that many of the Sub-Saharan African countries' economic outputs had fallen from 2.0 percent annual growth from 1966 to 1973, to a negative growth of (-0.7 percent annual growth) from 1985 to 1990; the report also went on to say that the economic growth was further down from 1991 through 1994 to -0.9 percent. The negative and damaging reports by the World Bank and others were believed to have been exacerbated by the Structural Adjustment Program (SAP) policies that were forced on many African countries by their creditors to fixed the economic problems in the 1980s (Onimode, 1992; Kellick, 1993 \& 1997; World Bank, 2000).

\section{The Universal Primary Education (UPE)/Universal Basic Education (UBE) in Nigeria}

Historically, since Nigeria gained her independence in 1960, efforts to reform and strengthens the educational system has not always worked as well as the people would have liked. However, the educational reforms in Nigeria dated back 
to pre-independence in 1955 when the then Western Regional Government of Nigeria implemented a compulsory Universal Primary Education scheme (UPE) that made primary education free for all children in the region. In his quest to historically traced the evolution of education reforms in Nigeria, Edho (2009) stated that

The origin of Nigeria's educational policies dates back to the 1955 comprehensive education laws of the Western Nigeria, 1957 Universal Primary Education (UPE) of the Eastern region and the 1976 UPE national programme; the 2000 Universal Basic Education (UBE) is the baby programme which is still been nurtured to maturity. (p. 184)

In 1999 at the outset of the newly democratically elected civilian government in Nigeria, after decades of military rule, a new educational scheme - the Universal Basic Education (UBE) was enacted and implemented. The UBE in essence was very similar to the UPE scheme that was tried in the mid and late 1950s through the 1970s. According to Aluede (2006), he described the UBE as "the whole people without exception," it's very similar to the No Child Left Behind scheme in the United States. He also stated that "Basic will mean that, on which anything rest. It is the root or bottom of the foundation from which other parts get support" (p. 97). Aluede argued that "The Federal Government's involvement in the organization of UBE scheme was therefore necessary if the integration of the nationals was to be achieved. The scheme was also desirable to enable the Federal Government ensure that children are taught the culture of the society" (p. 98). Moreover, Aluede believed that "Apart from the above statement, there is the need to lay a sound foundation for scientific and reflective thinking, character and moral training and the development of sound attitude, and above all, develop in the child the ability to adapt to his changing environment" (p. 99).

Even with the participation of both the federal and state governments in the UBE educational scheme, there seem to be very serious problematic issues facing the scheme. The schemes' failure goes back to the inadequate planning and implementations. Utibe (2001) argued that the then Universal Primary Education (UPE) of the first republic failed because there was inadequate planning on the part of the then regional governments; his assertion was that the programs were rushed through and not properly implemented. Aluede (2006) explained the failure of the schemes this way, he stated that

It has also been said that the forces that brought about the failure of a similar programme - the Universal Primary Education scheme are still very much around. These forces are - lack of proper planning, inability to project the estimated population that will be in school during the period, lack of knowledge of the number of teachers that will be required, inability to estimate the cost of providing the accurate number of school buildings, learning facilities and the financial implication of the entire programme. (p. 100)

Utibe (2001) went on to say that "additional factor that would bring about the failure of this UBE scheme is the quota admission policy that is being introduced with the scheme. This has never been accepted by the Nigerian populace" (p.100). After his analysis of the complicated and complex educational scheme in Nigeria, Aluede (2006) shared an optimistic tune with the following comment, he asserted that "However, the scheme, if properly implemented, particularly with adequate consideration given to the forces that could bring about its failure as identified above, will enhance Nigeria's educational and overall development" (p. 101).

\section{The Introduction of Private Universities in the Nigerian Educational System}

The emergence of the private sector into the educational system in Nigeria was a new phenomenon. The first time Nigeria tried to introduce private ownership of higher educational institutions was during the second republic when the then civilian government started allowing private individuals and entities to open and operates private universities in Nigeria. However, that scheme was shot-lived, because when the military juntas overthrew the civilian government and took over the control of the federal government in the mid-1980s, the program was shut down. For almost twenty years since then, the Nigerian educational system, especially at the university level, has been unable to accommodate the enormous admission entrance of the Nigerian students. Though, many reasons and excuses have been given as reasons why the educational system, at the college and university levels, was not able to meet the entrance demand of the students coming into the system. However, Ejiro-Akpotu and Akpochufo (2009) argued that

Resources required qualitative education has been scarce, while students' desire for university education continued to mount. Private sector participation in the provision and management of university education therefore, appear to ensure the production of quality graduates; bearing in mind that Nigeria is reputed to have the most dynamic and daring private sector in Black Africa. (p. 23)

The Nigerian National Universities Commission (NUC) in 2005 explained that the failure of the Nigerian tertiary institutions stemmed from the huge teacher-student ratio. In addition, there was the overcrowded of classes that exacerbated and led to examination malpractices; the inadequate and mediocre standards in teaching at the institutions, and the never-ending strikes by the university staff compounded on the problems. To truly understand the extent of the cost of the strikes, both in economic and absenteeism terms, Akpotu (2004) reported that a total of 99.55 weeks (which 
is equavelent to about three academic years) were lost from strikes by the Nigerian university staff within a period of six years. Per Akpotu's study, he explained that the lost time represented an enormous cost to the system, about fifty billion Naira (roughly $\$ 684$ million in 2013). All the aforementioned problematic issues were some of the contributory factors that led to the inability of the Nigerian public universities to structurally and financially able to accommodate and educate the vast majority of the Nigerian students who are leaving high schools for the universities. The statistical numbers of high school students transitioning from high schools to colleges and universities are enormous. Additionally, another issue facing the system is its inability to accommodate over 80 percent of the students who have applied and gained entrance into the university system. This is a compounded stressor on the already weak and fragile university system owned and operated by the federal and state governments.

According to JAMB (Joint Admission and Matriculation Board) 1988 through 2001 report, the report showed that the number of students who are admitted against the total students who applied to get into the university system in Nigeria were mindboggling. From 1978 to 1988 a total of 1,654,661 students applied to get into the Nigerian university systems, only 271,365 were admitted. Roughly about 1,383,296 (83.6\%) students were rejected. From 1989 to 1999 a total of 3,659,118 applied, but only 575,920 students were admitted, leaving a total of 3,083,198 (84.3\%) out of the university system. Finally, between 1999 and 2000 a total of 417,773 applied, only 78,550 students were admitted, leaving out $339,223(81.2 \%)$ students who are rejected by the Nigerian university system. These statistical numbers explicitly shows the extent at which the university system in Nigeria has deteriorated and broken; it also shows the shameful state of affairs at the university system in Nigeria. Perhaps because of the scalding and devastating numbers shown above, plus the ever increasing financial expenditures at the public university system pressured the Federal Government of Nigeria to expedite the approval process for the private sector to get into the ownership and management of universities in Nigeria. Moreover, Okebukola (2004) argued that in 2010 when the students admitted at the start of the UBE program begins to graduate and transitioning into higher education, the already broken Nigerian university system would not be able to absorb the expected $10 \%$ of those students who would want to attend higher education. As part of a partial solution, Abubakar (2004) suggested that Nigeria would need at least additional 70 universities in the following six years to absorb some of the students who would be left out of the system because of the inability of the Nigerian university system to accommodate them.

\subsection{Private universities in Nigeria}

The Nigerian private university system was modeled to cater to the need of the Nigerian business environment. Many of these universities were owned and managed as a "for profit" business enterprise and operated as such; many of the private universities' primary objectives were to cater to the needs of the marketplace and be profitable. Most of their curriculums and courses were business oriented and as such most of their students' intakes are very limited vis-à-vis from the enormous pool of the rejected university applicants. Belfied and Levin (2003) noted that the essence of private university is to be run and managed as though it's a business enterprise; they are not publicly owned and funded universities nor are they independently owned universities funded through secular and/or religious institutions. Ajadi (2010) noted that "the emergence of private universities as a business enterprise is an emerging phenomenon; a number of issues plagued its development including legal status, quality assurance and the cost of service" (p. 15). He went on to argue that "Another reason for the establishment of private universities in Nigeria is the effect of globalization. All over the world, private schools especially at the university levels have been responsive to the growing demand of education by qualified candidates" (p. 20). The advent and presence of globalization in every corner of the globe has made the need for borders and boundaries less important. Moreover, the essence of globalization is to open up all these borders for capital to seek out labor; and for labor to freely move around without hindrance or constraints. Recently, within the last 10 to 15 years, Africa has seen a dramatic change in foreign investments in the continent. This is one major phenomenon that is attributable to globalization and has taken Africa by storm; the free flow and movement of capital coming into the continent from places like China, Europe, North and South America, and Asia, is a huge phenomenon. With this kind of money and capital flowing into the continent, it is not surprising to see the growth of private schools and universities springing up everywhere in the continent.

On the international scene, the impacts of private schools and universities have also been incredible; according to the International Institute for Educational Planning (2003), they reported that the establishments of private universities have now become reality and the impacts has become very noticeable and felt around the world with the ever expanding presence of globalization. The incredible impact that the establishment of private universities have had in the continent of Africa have also been phenomenon and immeasurable. According to Taferra and Altbach (2003), they reported that the growth of private universities in Africa have changed the perspectives of many African students vis-à-vis their desire to pursue higher education. From their report, they gave the following numbers of private universities establishments in Africa: Kenya (13); Sudan (22); Ghana (11); Uganda (10); Togo (22); Ethiopia (20), and Madagascar (16). The growth of private universities in Nigeria took a slightly different path, because the military juntas, who took over the government in the 1980s, essentially discontinued the program. However, since 1999 when the third republic of the civilian government came to power, the numbers of private universities established has quadrupled.

Fascinatingly, the growth of private universities in Nigeria has only happened within the past 13 to 16 years; within this period, the country has seen the establishment of more than fifty private universities that has now surpassed the numbers of the federally owned and managed universities (approx. 40), and more than ten universities over the 
universities owned and managed by the state governments (approx. 38). However, there are concerns brewing in many quarters of the educational communities in Nigeria with regard to the quality of education that are coming out of these private universities. Many of these concerned citizens wanted to know if and how the private universities are been monitored (oversight) vis-à-vis the quality of their curriculums and courses. The truth is that even though the country has reformed and instituted a very strong market-based system where businesses and business opportunities of any kind are allowed to strive and flourish, the reality is that there is a lineage between strong education and economic growth and development. Nigeria needs to have a strong educational system that will ignite developmental growth in the country's economy. However, the government cannot afford to sit-bye and ignore the growth of the industry (private university ownerships), it is important that a "measured oversight" regulations be implemented to oversee the industry.

\section{Gender Education in Nigeria}

Obviously the growth of globalization and the ever increasing desires of young Nigerian women to attend universities have made it possible for the old taboo and paradigm of putting "women in their places" to be broken. There is now a sense of self-assurance and self-confidence about womanhood in Africa, especially in Nigeria. Women are now holding positions of authority that women could not have held or dreamt of before; they're enrolling in large number into the Nigerian university system; at the end of the day, these women are still our mothers, daughters, sisters, and wives. It is ironic that some skeptics have spoken of the demise of the Nigerian homes (families) if women are allowed to go into the workforce or aspired to broaden their intellectual skills and abilities. However, their skepticism have not come true and will probably never come true, because our society is better off and in better shape when women are equal participants in the affairs of the country. Actually, Africa will be better off if women are encouraged and inspired to hold leadership positions, because research studies have shown that women are better leaders than their male counterparts (Bass \& Avolio, 1994; Eagly \& Johnson, 1990; Eagly et al., 2003; Klenke, 1993; Mandell \& Pherwani, 2003; Powell \& Graves, 2003). Even though studies have shown that women are better at leadership roles than their male colleagues, there are still issues facing female students at universities in Nigeria. Females have been subjected to sexual harassments and sexual inappropriateness by some male university teaching staff. Odejide, Akanji and Odekunle (2006), alluded to the sexual malice that many female students in the university system have to face; they stated that "Even though official recognition of the existence of sexual harassment is evidence in the 1989 Ministry of Education Circular on Sexual Harassment in Education Institutions, there has been little institutional will in most Nigerian universities to set up the machineries for dealing with it” (p. 556).

The advent of globalization has also made it possible for women in Africa, especially in Nigeria, to broaden their God given skills and abilities and occupy the ultimate positions that their intellectual capacities have enabled them to occupy. However, to get to the pinnacle of leadership positions, women in Nigeria are still finding it difficult to break the invisible glass ceilings. For women to be truly seen as leaders, Nigerian society (both federal and state governments) would have to create a parity system where women are not discriminated against by the male chauvinists in the educational arena and in the society. Male chauvinist, especially African male chauvinists, believes that the place of women is in the home taking care of the children and cooking for the family, instead of going to schools and making something of themselves. Odejide, Akanji and Odekunle (2006) argues that

The lack of progressive policies and strategies to promote gender equity in higher education demonstrates that gender issues are not a priority at national and institutional levels. Rather, the initiatives to address gender disparity have been concentrated at lower levels of education and restricted to government and civil society. (p. 553)

Until recently, female entrance into the university system in Nigeria has been abysmal, particularly because the environment is male dominated (both as staff and students). Masculine-oriented society, like Nigeria, has made the prospect of women attending classes as students or holding leadership positions very difficult. It's also hard for women to feel enthused or engaged when the environment is not an equal level playing field for both genders; the gender inequality issues is not getting adequate support and encouragement, especially from the society and governments (GECHE, 2004). There is disparity between the two genders in higher education in Nigeria with 40 percent of women in the system and worse still fewer percentage in science and technology courses (Jibril, 2003, p. 492). Another troubling gender related issue in the Nigerian university system is the creation of curriculum based on "gendering of classroom participation." What this means is that male genders are made to dominant the classroom knowing very well that it will discourage and disempowered some females, thereby creating silence and discouragement among females in the classrooms (Lewis, 1994).

\section{Adult and community education in Nigeria}

Adult education is a new educational phenomenon in Nigerian, unlike in Europe and/or North America where adult education is an established educational phenomenon in those societies. The phenomenon hasn't caught on that well in Africa, or Nigeria. Though, the evolution of adult education have started to shift in Nigeria with the licensing of private ownership of universities and colleges, sooner rather than later, encouragement of adult programs will grow even faster than it is now. However, the problem with adult education in Nigeria is that the government hasn't created the environments where adult education is encouraged. Onyenemezu (2012) argues that "Adult education changes the 
social and psychological minds of adults more than any other profession, instills lost hope in them and liberates them from their prejudice of seeing themselves as not having the capacity to learn" (p. 1). More importantly, Onyenemezu noted that

With the world becoming a global village, adult education helps to breakdown stereotype ideas and reduces prejudice, injustice, deprivation and oppression. By implication, this means that adult education in addition to being a tool for global peace and harmony makes the educated adults to be more sophisticated and polished in their chosen professions. (p. 4)

Fasokun (2006) also noted that adult education is concerned not with preparing people for life, but rather with helping/assisting people (adult) to live more successfully as useful and acceptable members of their societies and contribute meaningfully to the development of those societies.

Perhaps the best way to change the paradigm of adult education in Nigeria is to encourage the expansion of community education in different communities in the country so that local folks can partake in the educational activities of their communities. Akande (2007) stated that "Community education is the type of education needed to ensure the selfconfidence, self-respect and personal independence as well as to safeguard human rights and achieve social equality" (p. 264). He went on to say that "Community education is essential in stimulating community members to actively participate in social activities, find or generate employment, increase their incomes and improve their quality of life" (p. 264). Minzey and le Tarte (1972) believes that the goals of community education is to develop the skills and abilities of adults learners, in the community, to work together to help improve the conditions of their communities. Community education is also described as an educational process that aimed to raise consciousness of people and provide the skills, human and material, needed to enhance and develop the economic, political and cultural development of the community (Ezimah, 2004).

\section{Special needs students in Nigeria}

Africans are well known for been kindhearted people; taking care and helping people in need is an African characteristic. However, as a continent and people, Africans have some ways to go with creating a strong institutional system that looks after the need of the disabled people in the continent. In Nigeria, there is a public discourse going on in the area of integration of special need students with able-bodied students in the same classroom to give them some kind of normalcy in life. According to the Institute of Democracy and Electoral Assistance (IDEA) act for people with disabilities, the act requires that a continuous placement options be made available for disabled students. The act also requires that as much as possible, children with disabilities should be educated with able-bodied children, and that every effort should be made to see to it that special classes and accommodations are provided for these disabled children. More importantly, the law made it pointedly clear that separate schooling or the remover of special need students from regular school can only be done if the nature of the situation is severe and necessitated the relocation of the special need students.

It is presumed that inclusive educational system is perhaps what everyone wants; no reasonable person would advocate for exclusive educational practice if the disabled students can adequately (or with reasonable assistance) learn and partake in the regular in-class activities. Many studies have described inclusive education as the inclusion of disability students in a regular school system (Bryant, Smith, \& Bryant, 2008; Lipsky \& Gartner, 1997; Rogers, 1993; Salend, 2001). Fakolade, Adeniyi and Tella (2009) argues that "For the child with a disability to benefit optimally from inclusion, it is imperative for general education teachers to be able to teach a wider array of children, including those with varying disabilities, and to collaborate and plan effectively with special educators" (p. 157). They went on to illustrate the lackluster implementation of the act (law) by the state governments that are supposed to enforce the law. They stated that "In practice however, it is only one state out of over thirty states that has actually started the implementation of the inclusive education at the primary school levels, other states of the federation in Nigeria are just starting up by creating a unit in each of the schools for their inclusive classrooms" (p. 157). Nigeria lacks the infrastructure and the technological know-how to successfully carry out this policy, because their educational system is not equipped to handle this kind of activities. Moreover, the system doesn't have the manpower and training background to embark on something as intricate and difficult as educating special needs students with able-bodied students, especially if those teachers have never been trained nor done it before. However, there is a cost-benefits that comes with this endeavor; according to Ajuwon's (2008) argument, he argues that it is obvious that the benefits of the inclusive education allows and encourage children with disabilities to be more incline to learn new social skills in an environment that is close to normal condition of growth and development.

Even though Nigeria is not where she needs to be in terms of her implementation of inclusive educational system for the disabled students in the country, at least she's working towards it. According to Fakolade, Adeniyi and Tella (2009), they stated that

The decade 1970-1980 could be rightly described as the golden period for the special needs children in Nigeria, because it was in the latter half of the decade that the Federal Military Government of Nigeria released the National Policy on Education in 1977 (in this document, issues related to 
inclusive education and equality were elaborated, especially as it concerns the right of education of

both the special needs children and the non-disabled children). (p. 158)

Elliot (2008) also found out that the fears of some educators' vis-à-vis the disruptive chaos that the changes would cause in the classrooms were unfounded, because what he found was that the relationship between teachers with attitudes toward inclusive education and their effectiveness in the classroom were at a high level. He's study shows that teachers with a positive attitude toward inclusive education provided their students with a high practice attempts and ended up with a higher level of success.

\section{Conclusion}

After so much research and revision of articles on education in Nigeria, I've come to the conclusion that the educational system and standards in Nigeria have quite some ways to go. However, the good thing going for this country is the fact that her people are full of resiliency, and they are a "can do" people. The truth of the matter is that in this global world that we live in, education is the utmost investment that any nation can invest in their young people. Education goes hand-in-hand with economic growth and any other developmental growths that a country like Nigeria could aspire to achieve. Thus it is important for both the Nigerian government and her people to understand that without a strong and viable educational system, there cannot be a flourishing middleclass or economic prosperity in the country. For a good educational reform to take hold in a place like Nigeria, the first thing that need to be done is the introduction of a strong early childhood educational system that will strongly focus on educating young children from early age. With this kind of investment in early childhood education, it will create a new paradigm (mindset) in the psyches of Nigerian parents' and people.

The pioneers of the early childhood education; Pestalozzi, Froebel, and Herbert, advocated for strong early childhood education intervention for young children. Friedrich Froebel's strong insight and understanding into early childhood education afforded him the opportunity to recognize the need for a kindergarten system for young children of preschool age. This system will prepare children and give them heads up into the concept of education before they even get into the regular schooling system. Such a system is what Nigeria need; a system that focuses on the interests of the children, and uses different learning tools and mechanics to encourage and motivate children to want to learn. Johann Heinrich Pestalozzi (1969), one of the formidable and father of early childhood education, stated in his book titled "The education of man: Aphorisms" that "The crowning achievement of education is to reach the child's heart to convince him [or her] of our fervent love at the very moment when we are pointing out mistakes and are seeking to break a bad habit" (p. 33); in essence what he was saying was that education should not be a "boogeyman" experience for children, but a process that encourages children while they're been taught new ideas and knowledge.

The other observation that might help with the current educational problems in Nigeria is the issue of investing in technology. It is highly recommended that the Nigerian government start to implement policies that invest and encourage the building of technological infrastructures all across the country. It is mindboggling that a country as rich in human and mineral resources could not boost of good stable information and communication technology that allows interactive communications among her people. One major priority of the Nigerian government should be the implementation of the much needed technological infrastructures that will ignite economic and educational growths and developments in the country.

Finally, the issue of equal opportunities for every demographics in the country should strongly be enforced through public education. The public education of equality should be conducted through the media outlets in Nigeria, i.e., Television, radio, newspapers, etc. More importantly, the concept of equality in the society should be encouraged through the use of local and traditional means of education, i.e., local village/town chieftaincies, local village/town public gatherings, through local newspapers, through college newsletters, etc. It should be made clear to ordinary Nigerians that discrimination based on gender and/or sexual harassment perpetuated by someone in authority will not be tolerated and will be prosecuted to the fullest of the law. Hopefully, if these kinds of messages are relayed and continuously reiterated every time, people will pay attention and start to get the message. But the key is that it has to be reiterated on consistent bases so that it discourages offenders and encourages the expected behavior.

Even though Nigerians may not have a lot to give, they are truly known for being generous with the little that they have. However, in some studies that were conducted to understand the attitudes of teachers toward the inclusion of 'hard-ofhearing' students in general education classrooms, majority of the teachers who were asked were against the idea. They felt that they were inexperienced, ill-trained and ill-prepared to take on a serious issue as caring for special needs students (Mba, 1991; Ogbue, 1995). However, at the end of the day, the fact still remains that there is a significant population of students who will be excluded based on their physical and/or mental disabilities. These kinds of discriminatory behaviors and attitudes should never be acceptable or tolerated under any circumstances in any society. 


\section{References}

Abubakar, M. (2004). Why Nigeria needs 70 universities in six years by Okebukola? The Guardian, Tuesday, August 19, 2004, 49-51.

Ajadi, T. O. (2010). Private universities in Nigeria - the challenges ahead. American Journal of Science Research, 7 , 15-24. www.eurojournals.com/ajsr,htm

Ajuwon, P. M. (2008). Inclusion education fixes students with disabilities in Nigeria: benefits and challenges and policy implications. International Journal of Special Education, 23(3), 11-16.

Akande, J. O. (2007). The practice of community education in Nigeria. Educational Research and Review, 2(10), 264270. www.academicjournals.org/ERR

Akani, C. (2013). Globalization and the myth of human rights in Africa. Wudpecker Journal of Educational Research, 2(2), 019-025.

Akpotu, N. E. (2004). Analysis of the cost of national strikes in Nigeria University (1999-2003). Higher education review, 37(1), 49-58.

Aluede, R. O. A. (2006). Universal basic education in Nigeria: Matters arising. Journal of human ecology, 20(2), 97101.

Aluko, M. A. O. (2002). The institutionalization of corruption and its impact on political culture and behaviour in Nigeria. Nordic Journal of African Studies, 11(3), 393-402.

Asodike, J. D., \& Ikpitibo, C. L. (2014). Basic issues in primary education delivery in Nigeria. European Scientific Journal, ESJ, 8(1).

Augustine, E. A., \& Uagbale-Ekatah, R. E. (2014). The Growing Relevance of Forensic Accounting as a Tool for Combating Fraud and Corruption: Nigeria Experience. Research Journal of Finance and Accounting, 5(2), 71-77. www.iiste.org

Bass, B. M., \& Avolio, B. J. (1994). Shatter the glass ceiling: women may make better managers. Human Resources Management, 32(4), 549-560.

Belfied, C. R., \& Levin, H. M. (2003). Educational privatization: causes, consequences and planning implication. International Institute for Educational Planning (IIEP). Paris: UNESCO.

Bryant, D. P., Smith, D. D., \& Bryant, B. R. (2008). Teaching students with special needs in inclusive classrooms. Boston, MA: Pearson Education, Inc.

Dike, V. E. (2005). Corruption in Nigeria: A new paradigm for effective control. Africa Economic Analysis, 24(08), 122.

Eagly, A. H., Johannesen-Schmidt, M. C., \& Van Eugen, M. L. (2003). Transformational, transactional and laissez-faire leadership styles: a meta-analysis comparing women and men. Psychological Bulletin. American Psychological Association, 129(4), 589-591.

Eagly, A. H., \& Johnson, B. T. (1990). Gender and leadership style: A meta analysis. Psychological Bulletin, 108(2), 233-256.

Edho, O. G. (2009). The challenges affecting the implementation of the universal basic education (UBE) in Delta State, Nigeria. Journal Social Science, 20(3), 183-187.

Ejiro-Akpotu, N., \& Akpochufo, W. P. (2009). An analysis of factors influencing the upsurge of private universities in Nigeria. Journal of Social Science, 18(1), 21-27.

Elliot, S. (2008). The effect of teachers' attitude towards inclusion on the practice and success levels of children with and without disabilities in physical education. International Journal of Special Education, 23(3), 48-55.

Ezimah, M. O. A. (2004). Knowing adult education: it's Nature, scope and processes. Owerri: Springfield Publishers Limited.

Fakolade, O. A., Adeniyi, S. O., \& Tella, A. (2009). Attitude of teachers towards the inclusion of special needs children in general education classroom: the case of teachers in some selected schools in Nigeria. International Electronic Journal of Elementary Education, 1(3), 155-169.

Fasokun, T. O. (2006). Non-formal education as a Nigerian strategy for the actualization of the United Nations Millennium development goal, An opening address delivered at the Nigerian National Council for Adult Education (NNACAE) conference. Calabar: Nigeria, Nov. 27 - Dec. 1, 2006.

Federal Ministry of Education (1989). Sexual Harassment and examination malpractice. Unpublished Report.

Gender Equity in Commonwealth Higher Education (GECHE) (2004). Working paper1: Setting the scene Retrieved from: www. ioe.ac.uk/efps/GenderEqComHE

Geo-Jaja, M. A. (2005). Globalisation, education reforms and policy change in Africa: the case of Nigeria. J. Zajda (ed.). International Handbook on Globalisation, Education and Policy Research. 517-536. 
International Institute for Educational Planning (IIEP) Newsletter (2003). XXI, 2003, 5-11.

Jibril, M. (2003). Nigeria. In Damtew Teferra \& Philip Altbach (Eds.), African higher education: An international reference handbook. Bloomington: Indiana University Press.

Joint Admission and Matriculation Board (JAMB) (1988, 1999, \& 2001). Statistical digests. www.jambng.com

Kellick, T. (1993). The adaptive economy, adjustment policies in small, low-income countries. Washington DC: The World Bank.

Kellick, T. (1997). Principles, agent and the failings of conditionality. Journal of International Development, 9 , 497506.

Klenke, K. (1993). Meta-analytic studies of leadership: added insight or added paradoxes? Current Psychology, 12(4), 326.

Lewis, M. (1994). Without a word: teaching beyond women's silence. London: Routledge.

Lipsky, D. K., \& Gartner, A. (1997). Inclusion and school reform: Transforming America's classrooms. Baltimore, MD: Brookes Publishing Co.

Mandell, B., \& Pherwani, S. (2003). Relationship between emotional intelligence and transformational leadership style: a gender comparison. Journal of Business and Psychology, 17(3), 387-404.

Mazrui, A. (1999). From slave ship to space ship: Africa between marginalization and globalization. African Studies Quarterly, 2(4).

Mba, P. O. (1991). Elements of special education. Ibadan: Codat Publication Nigeria.

Minzey, J. D., \& le Tarte, C. (1972). Community education: From program to progress. Michigan: Penoless Publishing Company.

Nigerian National Universities Commission (2005). NUC newsletter. Abuja: National Universities Commission.

Odejide, A., Akanji, B., \& Odekunle, K. (2006). Does expansion mean inclusion in Nigeria higher education? Women's Studies International Forum, 29, 552-561. www.elsevier.com/locate/wsif

Ogbeidi, M. M. (2012). Political leadership and corruption in Nigeria since 1960: A socio-economic analysis. Journal of Nigeria Studies, 1(2).

Ogbue, R. M. (1995). Report of the survey of special education facilities in Nigeria. Lagos: Federal Government Press.

Ogundiya, I. S. (2009). Political corruption in Nigeria: Theoretical perspectives and some explanations. Anthropologist, 11(4), 281-292.

Okebukola, P. (2004). The choice and balance between quality and quantity in the Nigerian university system: Admission Quota for 200/2006 National Universities Commission. Monday Memo, 4(21), 1-4.

Okoye, G. O. (2016). The impact of forensic accounting on investigation of corporate fraud in Nigeria: Study of EFCC. Global Journal of Applied, Management and Social Sciences, 11(February), 145-163.

Onimode, B. (1992). African alternatives to World Bank and IMF programmes. In Paper presented at the IFAA Conference on 'Alternative Development Strategies for Africa'.

Onyenemezu, E. C. (2012). Adult education and the challenges of the $21^{\text {st }}$ century in Nigeria. Journal of Education and Practice, 3(5), 1-6.

Pestalozzi, J. H. (1969). The education of man: Aphorisms. Greenwood Press.

Powell, G. N., \& Graves, L. M. (2003). Leading people, women and men in management. (3 ${ }^{\text {rd }}$ Ed.). Sage Publication, Newbury Park, CA.

Rogers, J. (1993). The inclusion revolution. Research Bulletin. No. 11. Bloomington, IN: Delta Kappan, Center for Evaluation, Development, and Research. May.

Salend, S. J. (2001). Creating inclusive classrooms: effective and reflective practices for all students. Fifth Edition., New Jersey: Pearson Education, Inc.

Taferra, D., \& Altbach, P. G. (2003). African higher education: challenges for the $21^{\text {st }}$ century higher education. Netherland: Kluwer Academic Publishers.

UNESCO (1998). Education in the twenty first century: Vision and action. Paris: UNESCO.

Utibe, O. (2001). Issues and problems in the effective implementation of the UBE in Uyo L.G.A of Akwa Ibom State, B.Ed project (Unpublished), Uyo: University of Uyo.

World Bank (1996). African Development Indicators. Washington: The World Bank.

World Bank (2000). Can Africa claim the 21 st century? Washington DC: World Bank. 